\title{
(10) Norræna
}

ráơherranefndin

\section{Norrænt samstarf um norðurskautssvæðið}

\author{
Samstarfsáætlun Norrænu \\ ráôherranefndarinnar um \\ norðurskautssvæðið 2018-2021
}

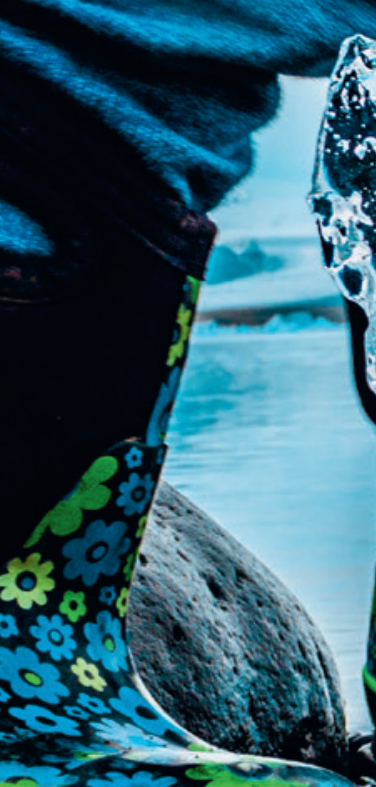

and

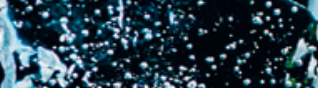

(16. winadon

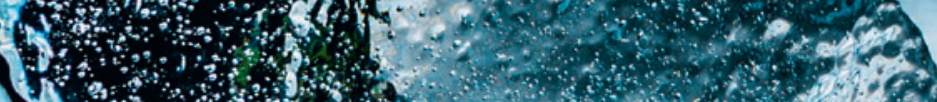

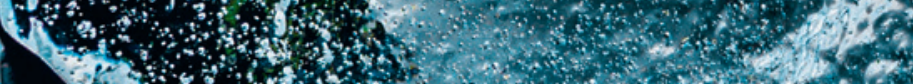
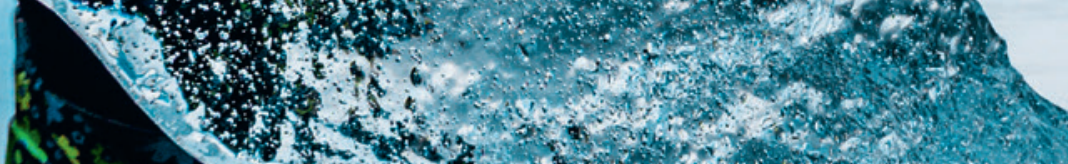

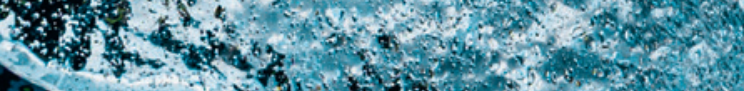
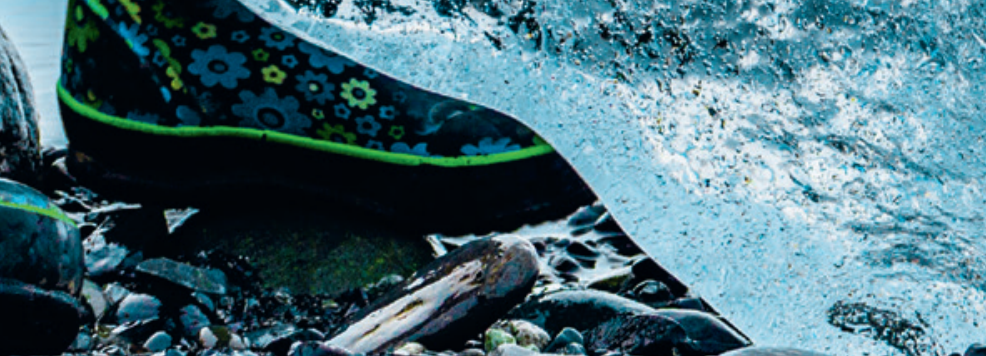

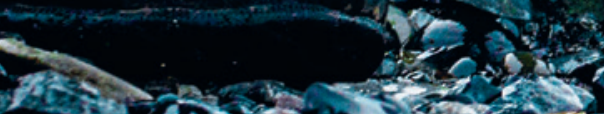

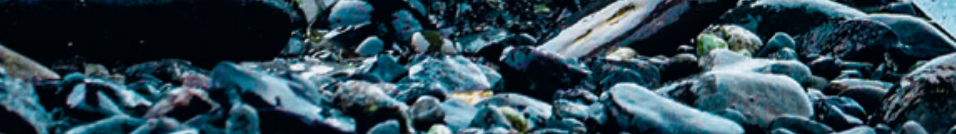

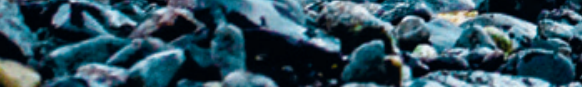
$20 \sin 2$

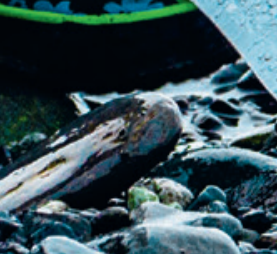




\section{Norrænt samstarf um norðurskautssvæðið}

Samstarfsáætlun Norrænu ráðherranefndarinnar um norðurskautssvæðið 2018-2021

ANP 2017:764

ISBN 978-92-893-5172-O (PRINT)

ISBN 978-92-893-5173-7 (PDF)

ISBN 978-92-893-5174-4 (EPUB)

http://dx.doi.org/10.6027/ANP2017-764

(c) Norræna ráðherranefndin 2017

Umbrot: Louise Jeppesen

Kápumynd: unsplash.com

Printed in Denmark

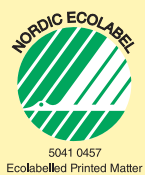

\section{Norrænt samstarf}

Norræna samstarfið er eitt umfangsmesta svæðasamstarf í heiminum. Samstarfið byggir á landfræðilegri legu landanna, sameiginlegri sögu peirra og menningu. Að samstarfinu koma Danmörk, Finnland, Ísland, Noregur og Svípjóð auk Álandseyja, Færeyja og Grænlands.

Norræna samstarfið er pólitískt, efnahagslegt og menningarlegt og skiptir miklu í evrópsku og alpjóðlegu samstarfi. Löndin vinna saman að pví að marka Norðurlöndum stöðu í öflugri Evrópu.

Með norrænu samstarfi er unnið að pví að gæta hagsmuna svæðisins og efla norræn gildi í hnattrænum heimi. Sameiginleg gildi landanna styrkja stöðu Norðurlanda og skipa peim meðal peirra svæða í heiminum par sem nýsköpun og samkeppnishæfni er mest.

\section{Norræna ráoherranefndin}

Nordens Hus

Ved Stranden 18

1061 København $\mathrm{K}$

www.norden.org

Sækja útgefið efni: www.norden.org/nordpub 


\section{Norrænt samstarf um norðurskautssvæðið}

Samstarfsáætlun Norrænu ráoherranefndarinnar um norðurskautssvæðið 2018-2021

05 Formáli

07 Tilgangur

09 Markmið

10 Forgangsverkefni og málefni

13 Skipulag

14 Viðmið

17 Samskipti, sýnileiki og mat

18 Fjárhagsáætlun

19 Athugasemdir 

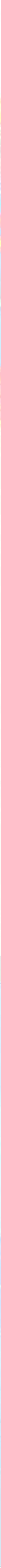


\section{Formáli}

Í samstarfsáætlunum Norrænu ráðherranefndarinnar er greint frá helstu pólitísku forgangsverkefnum viðkomandi fagsviðs á gildistíma áætlunarinnar. Norræna ráoherranefndin hefur haft samstarfsáætlun um norðurskautssvæðið síðan 1996 og áætlunin árin 2018-2021 er sú áttunda î röðinni. Áður en samstarfsáætlunin um norðurskautssvæðið fékk núverandi mynd árið 1996 vann Norræna ráðherranefndin líka að málefnum norðurskautssvæðisins með rannsóknaráætlun fyrir norðurskautssvæðið og umhverfis- og náttúruáætlun.

Norræna ráoherranefndin hefur pví unnið samfellt og sérstaklega með norðurskautssvæðið síðan á dögum Rovaniemi-verkefnisins og stofnunar áætlunar til verndunar umhverfis norðurskautsins, Arctic Environmental Protection Strategy (AEPS), í upphafi tíunda áratugar tuttugustu aldarinnar fram til stofnunar Norðurskautsráðsins árið 1996 og að núverandi og framtídardagskrá norðurskautssvæðisins, sem snýst ekki lengur eingöngu um umhverfismál og náttúruvernd, heldur líka sjálfbæra próun í heild sinni. Petta felur meðal annars í sér að áætlun norðurskautssvæðisins snýst í auknum mæli um viðbrögð við og aðlögun að loftslagsbreytingum; almenn lífskjör íbúanna, par á meðal frumbyggjanna og óskina um áframhaldandi bætt lífskjör, hagvöxt og próun atvinnutækifæra; nýsköpun og frumkvöðlastarf sem og menntun og færnipróun.
Norðurskautssvæðið er svæði sem er að próast og par sem pörf er fyrir meðvitað, kerfisbundið og samfellt samstarf sem miðar að pví að skapa ferli og próun um frið, stöðugleika, verndun, hagvöxt og velmegun. Norðurskautssvæðið er svæði sem bæði parf að varðveita og próa. Pví gegnir hugtakið sjálfbær próun norðurskautssvæðisins lykilhlutverki fyrir ekki bara samstarfsáætlunina um norðurskautssvæðið árin 2018-2021, heldur líka sögulega séð fyrir allar pær samstarfsáætlanir um norðurskautssvæðið sem Norræna ráðherranefndin hefur haft síðan 1996.

Norræna ráðherranefndin vill með samstarfsáætluninni um norðurskautssvæðið fyrir árin 2018-2021 áfram vinna að pví að skapa og stuðla að sjálfbærri próun á norðurskautssvæðinu. Styrkur samstarfsáætlunarinnar um norðurskautssvæðið felst í breidd áætlunarinnar og getunni til að ná til lítilla aðila og hagsmunaaðila á norðurskautssvæðinu. Um leið á samstarfsáætlunin um norðurskautssvæðið líka að vera markviss og skýr og geta stuðlað að stefnumótandi verkefnum og niðurstöðu. Verkefni á vegum áætlunarinnar eiga að finnast innan pessa ramma. 


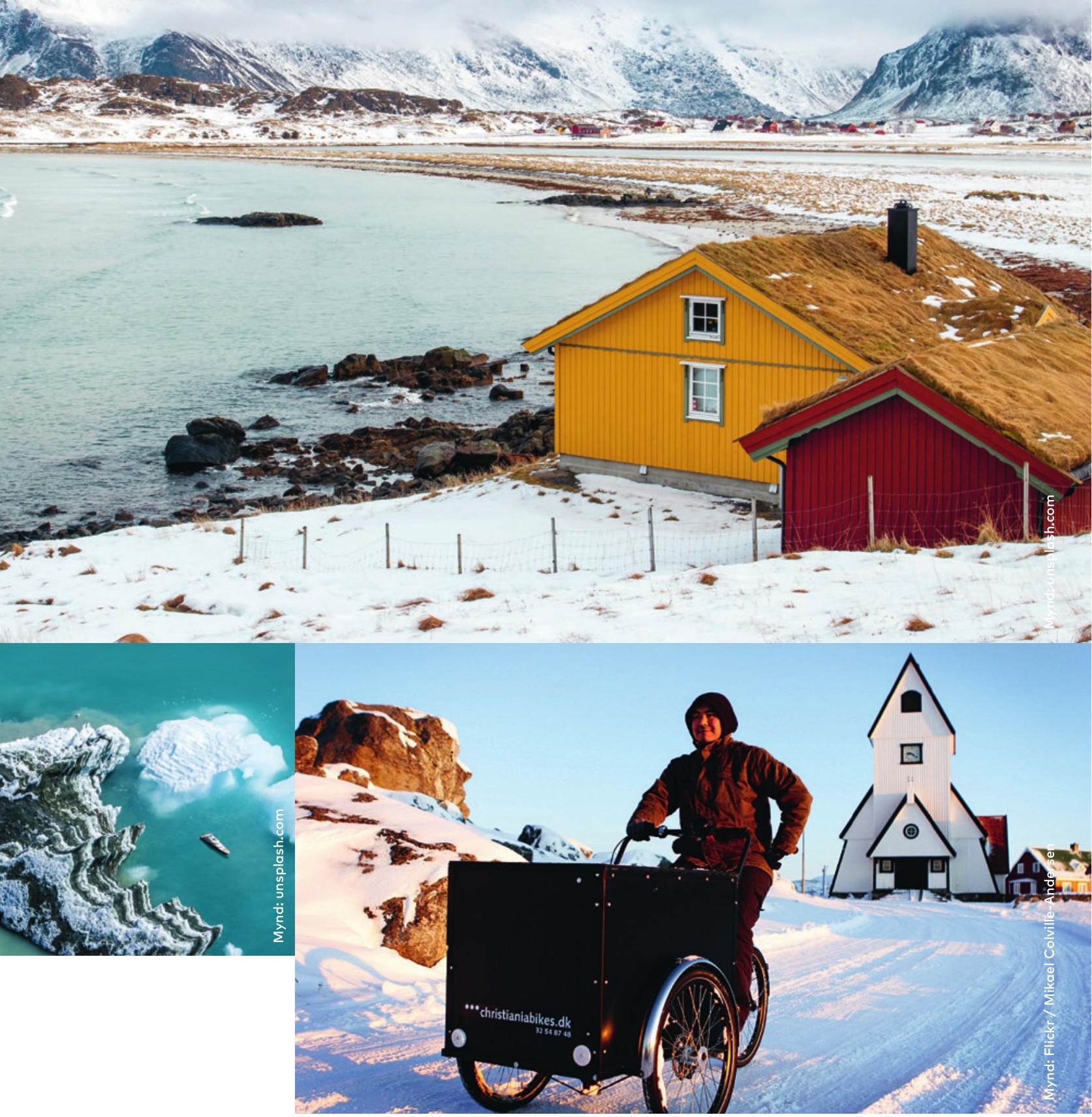




\section{Tilgangur samstarfsáætlunar Norrænu ráðherranefndarinnar um norðurskautssvæðið 2018-2021}

Samstarfsáætlunin um norðurskautssvæðið stuðlar að framtíðarsýn Norrænu ráðherranefndarinnar um nýskapandi, landamæralaus, sýnileg og opin

Norðurlönd. Samstarfsáætlunin á um leið að bæta upp aðra pverfaglega stefnu Norrænu ráðherranefndarinnar ${ }^{1}$, sem er sterk staða Norðurlanda og svið par sem vinna Norrænu ráðherranefndarinnar stendur vel að vígi bæði á Norðurlöndum og á alpjóðavísu og getur skapað virðisauka. Samstarfið innan Norrænu ráðherranefndarinnar, p.m.t. samstarfsáætlunin um norðurskautssvæðið, á sér rætur í norrænni hefð sem byggir á réttindum, sögulegri og lagalegri hefð lýðræðis og pátttöku.

Lykilmál í samstarfsáætlun Norrænu ráðherranefndarinnar um norðurskautssvæðið 2018-2021 mun verða að koma til móts við sértækar parfir norðurskautssvæðisins og stuðla að sjálfbærri próun norðurskautssvæðisins. Í pví samhengi gegna Dagskrá $2030^{2}$ og sjálfbærnimarkmiðin $17^{3}$, sem voru sampykkt á allsherjarpingi SP haustið 2015, stóru hlutverki.

Tilgangur samstarfsáætlunar Norrænu ráðherranefndarinnar um norðurskautssvæðið 2018-2021 er að skapa sjálfbæra og uppbyggilega próun norðurskautssvæðisins og íbúa pess á grundvelli fimm (ensku) péanna: PLANET (plánetan); PEOPLES (íbúarnir); PROSPERITY (hagvöxtur og velmegun); PEACE (öryggi og stöðugleiki) og PARTNERSHIPS (að pessi próun verði til í alpjóðlegri samvinnu). Einkum alpjóðlega samvinnan er páttur, sem Norræna ráðherranefndin hefur löngum lagt mikla áherslu á og leitast við að sampætta pverfaglega á öllum stigum áætlunarinnar og sú áhersla mun haldast. 


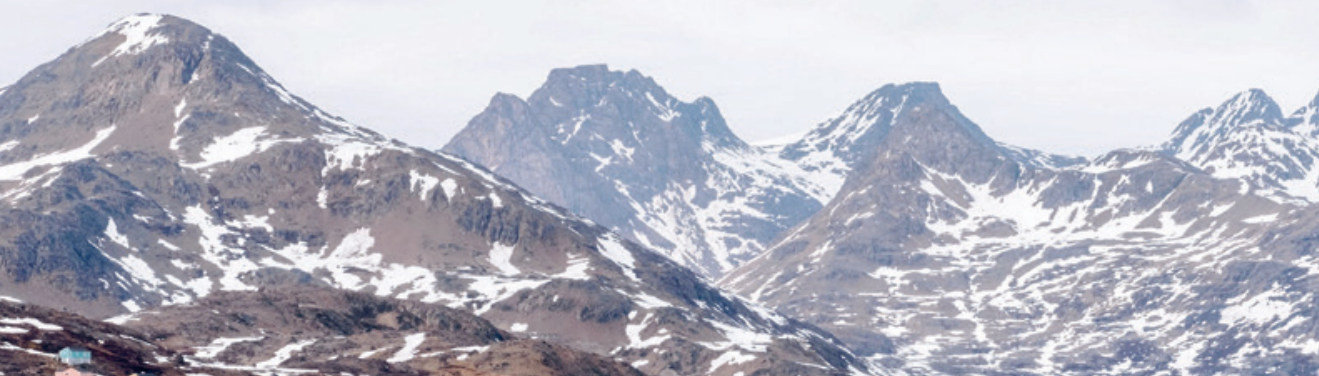

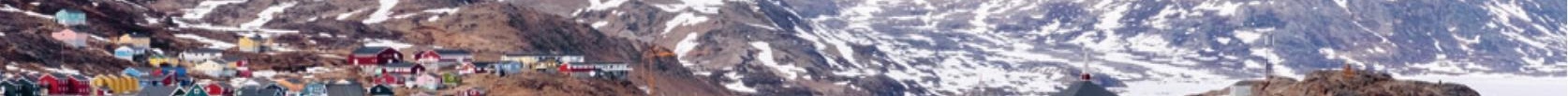

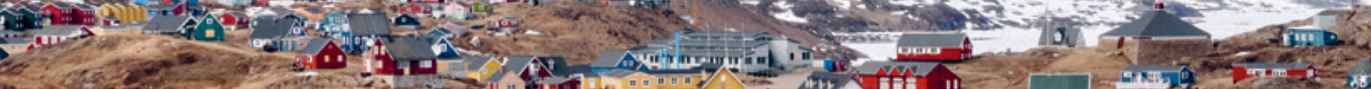

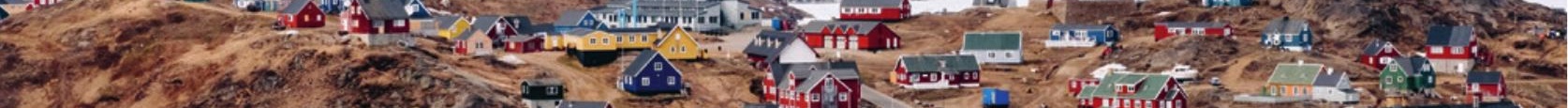

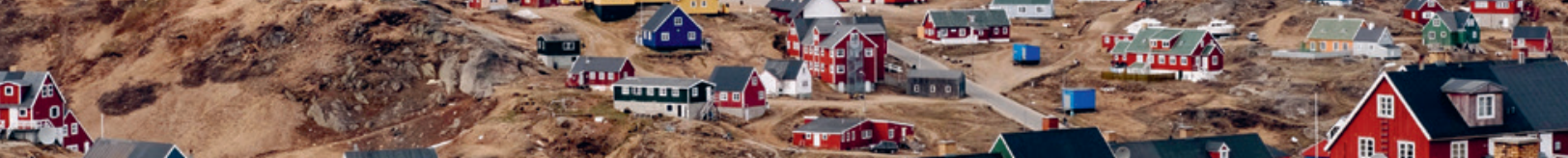
E- ami

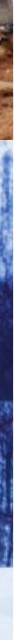




\section{Markmið í samstarfsáætlun Norrænu ráðherranefndarinnar um norðurskautssvæðið 2018-2021}

Í almennri vinnu sinni að sjálfbærnimálum vinnur Norræna ráðherranefndin samkvæmt Dagskrá 2030 og sjálfbærnimarkmiðunum 17 og öll 169 undirmarkmiðin eru viðeigandi frá almennum norrænum sjónarhóli. í samstarfsáætluninni um norðurskautssvæðið 2018-2021 er pó ekki hægt að verða við öllum sjálfbærnimarkmiðunum og forgangsröðunin hér á eftir endurspeglar hvaða sjálfbærnimarkmiðum sjónum verður beint að.
Forgangsröðunin í samstarfsáætluninni um norðurskautssvæðið mun taka mið af próun varðandi plánetuna (PLANET); varðandi íbúana (PEOPLE(S)); varðandi hagvöxt og velmegun (PROSPERITY), og sérstök áhersla verður lögð á að skapa pessa próun í samstarfi og albjóðlegri samvinnu (PARTNERSHIPS).
OSJÁLFBAER

PRÓUNARMARKMIĐ

17 MARRMUO TL AS BRETTA HEMINUM
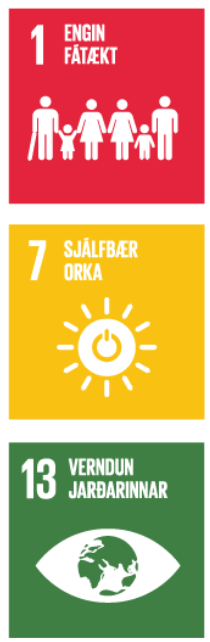
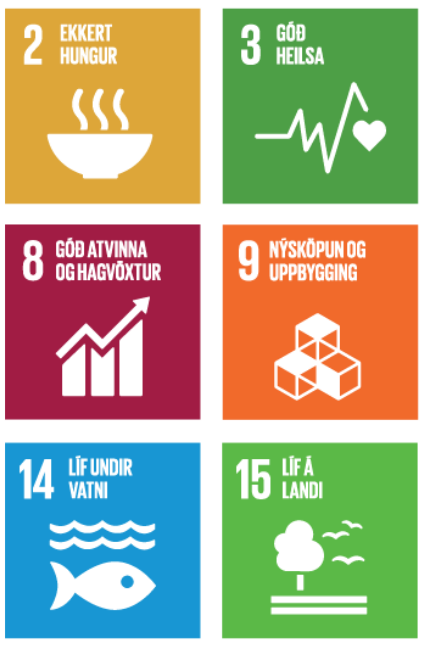

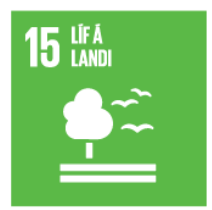

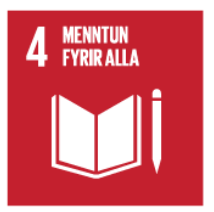
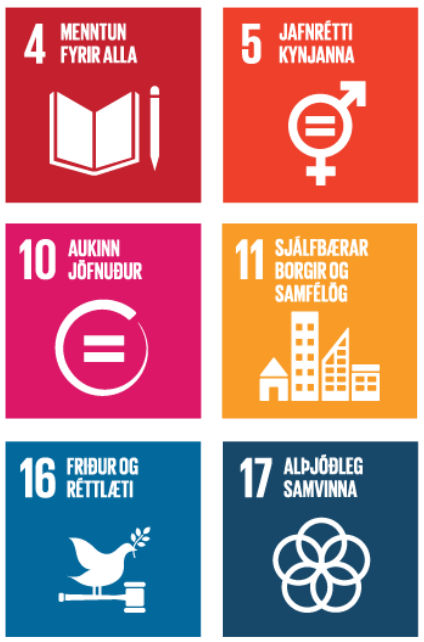
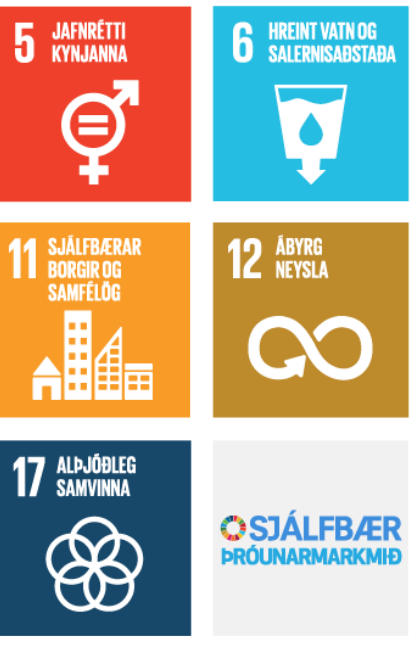


\section{Forgangsverkefni og málefni í samstarfsáætlun Norrænu ráðherranefndarinnar um norðurskautssvæðið 2018-2021}

\section{PEOPLES (PJÓĐIR)}

I forgangsverkefninu PEOPLES eiga eftirfarandi sjálfbærnimarkmið (SDG) við um samstarfsáætlunina um norðurskautssvæðið: SDG nr. 3 (góð heilsa), SDG nr. 4 (menntun fyrir alla), SDG nr. 5 (jafnrétti kynjanna), SDG nr. 11 (sjálfbærar borgir og samfélög), SDG nr. 16 (friður og réttlæti) og SDG nr. 17 (alpjóðleg samvinna).

Í samstarfsáætlun Norrænu rádherranefndarinnar um norðurskautssvæðið munu ofangreind sjálfbærnimarkmið í málaflokknum PEOPLES verða nýtt til að greiða fyrir og efla samstarfsverkefni og samskipti á eftirtöldum sviðum:

- Frumbyggjar á norðurskautssvæðinu

- Lífskjör fjölskyldna, einkum barna og ungmenna

- Jafnrétti og hlutverk kynjanna á norðurskautssvæðinu

- Heilbrigðismál og félagslegar aðstæður á norðurskautssvæðinu

- Rannsóknir, menntun og færnipróun á norðurskautssvæðinu

- Samstarf pjóða, grasrótarsamstarf og samstarf frjálsra félagasamtaka ásamt próun borgaralegs samfélags með tilliti til pess að efla friðsamleg lýðræðissamfélög með pátttöku allra.

\section{PLANET (PLÁNETA)}

Í forgangsverkefninu PLANET eiga eftirfarandi sjálfbærnimarkmið við um samstarfsáætlunina um norðurskautssvæðið: SDG nr. 6 (hreint vatn og salernisaðstaða), SDG nr. 7 (sjálfbæær orka), SDG nr. 11 (sjálfbærar borgir og samfélög), SDG nr. 13 (verndun jarðarinnar), SDG nr. 14 (líf undir vatni), SDG nr. 15 (líf á landi) og SDG nr. 17 (albjóðleg samvinna).

Í samstarfsáætlun Norrænu ráðherranefndarinnar um norðurskautssvæðið munu ofangreind sjálfbærnimarkmið í málaflokknum PLANET verða nýtt til að greiða fyrir og efla samstarfsverkefni og samskipti á eftirtöldum sviðum:

- Nýskapandi lausnir á sviði sjálfbærrar orku á norðurskautssvæðinu

- Sjálfbærar borgir og borgarbróun á norðurskautssvæðinu

- Sjálfbær nýting og notkun auðlinda hafsins

- Viðurkenning á mikilvægi líffræðilegs fjölbreytileika og breytinga á norðurskautssvæðinu

- Minnkun gróðurhúsalofttegunda, aðlögun að breyttu loftslagi og viðnámspolin samfélög á norðurskautssvæðinu 


\section{PROSPERITY (VELMEGUN)}

Í forgangsverkefninu PROSPERITY eiga eftirfarandi sjálfbærnimarkmið við: SDG nr. 4 (menntun fyrir alla), SDG nr. 7 (sjálfbær orka), SDG nr. 8 (góð atvinna og hagvöxtur), SDG nr. 9 (nýsköpun og uppbygging), SDG nr. 11 (sjálfbærar borgir og samfélög), SDG nr. 12 (ábyrg neysla) og SDG nr. 17 (alpjóðleg samvinna).

Í samstarfsáætlun Norrænu ráðherranefndarinnar um norðurskautssvæðið munu ofangreind sjálfbærnimarkmið í málaflokknum PROSPERITY verða nýtt til að greiða fyrir og efla samstarfsverkefni og samskipti á eftirtöldum sviðum:

- Nýsköpun og frumkvöðlastarf, par á meðal menntun í nýsköpun/ frumkvöðlastarfsemi og rekstri sprotafyrirtækja

- Stafræn tæknipróun

- Próun atvinnutækifæra á svæðinu

- Mikilvægi menningarinnar fyrir sjálfbæra framtíð á norðurskautssvæðinu

- Hentugar atvinnugreinar á norðurskautssvæðinu, par á meðal ferðapjónusta, matarmenning og útflutningur á matvælum frá norðurskautssvæðinu.

\section{PARTNERSHIPS (ALPJÓĐLEG}

\section{SAMVINNA)}

I forgangsverkefninu PARTNERSHIPS eru tvö sjálfbærnimarkmið mest viðeigandi, SDG nr. 16 (friður og réttlæti) og SDG nr. 17 (alpjóðleg samvinna), sem tæki til pess að ná fram peirri próun sem stefnt er að. Framtíðarsýn norræns samstarfs frá árinu 2014 er saman erum við öflugri. Detta er viðurkenning á að í samstarfi megi uppskera niðurstöður, reynslu, lausnir og virðisauka, sem er meiri en ef löndin hvert í sínu lagi eða einn aðili ynni verk eða verkefni. Norræna ráðherranefndin byggir á sameiginlegum norrænum lýðræðislegum hefðum og vinnur á grundvelli einkunnarorðanna norrænt notagildi, par sem samstarf tveggja eða fleiri norrænna ríkja skapar virðisauka, sem ella næðist ekki.

Samstarfsáætlun Norrænu ráðherranefndarinnar um norðurskautssvæðið er pví samkvæmt skilgreiningu áætlun, sem greiðir fyrir samstarfi og alpjóðlegri samvinnu og mun halda pví áfram til að ná fram skýrri niðurstöðu og lausnum við áskorunum og pörfum á norðurskautssvæðinu. Samstarfsáætlunina um norðurskautssvæðið má pví nota til að skapa og koma á fót tengslanetum og vettvangi með tilliti til að auka frjálst flæði fólks og miðlun reynslu á sviðum sem henta áætlun norðurskautssvæðisins. 

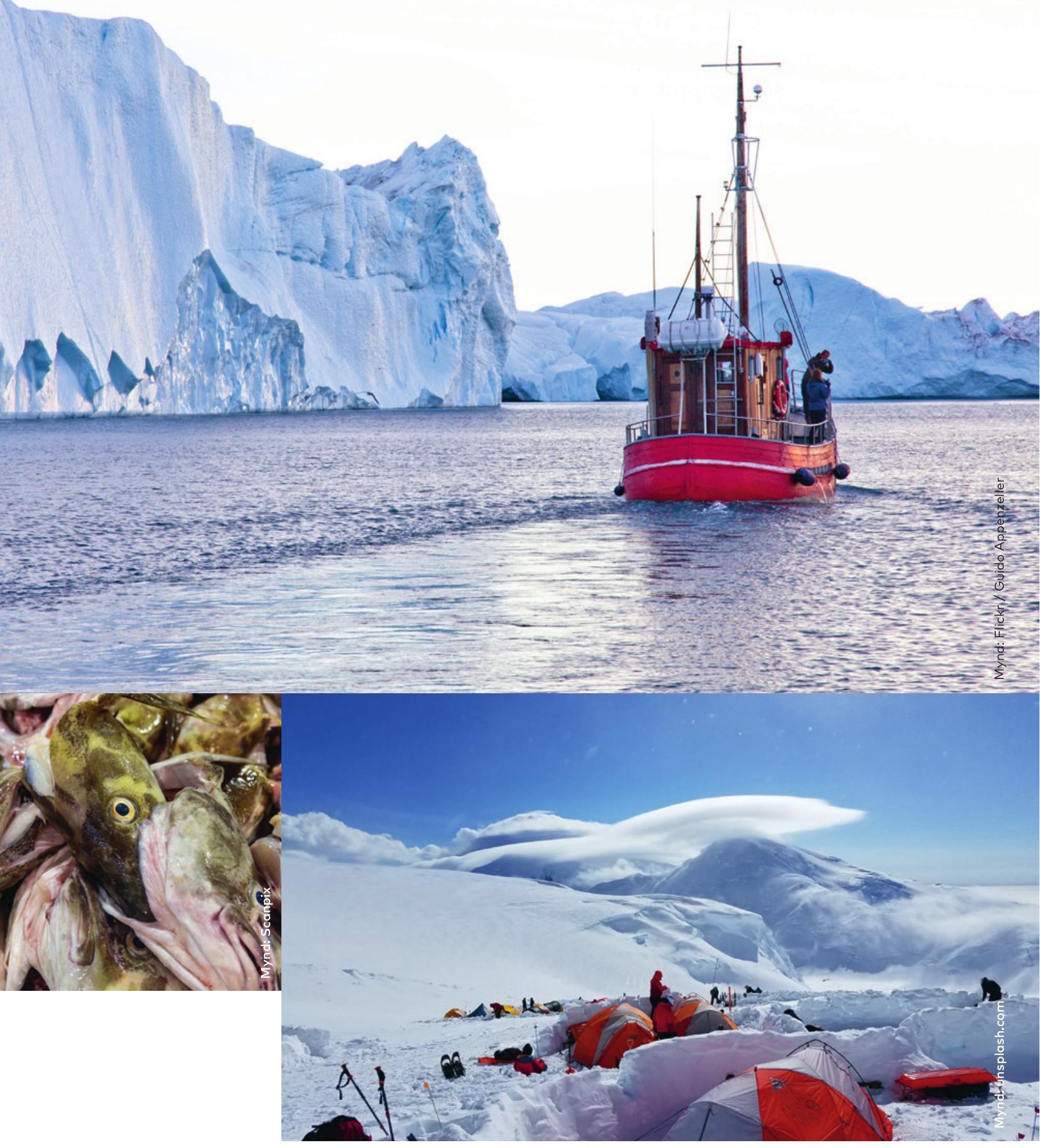


\section{Skipulag samstarfsáætlunar Norrænu ráðherranefndarinnar um norðurskautssvæðið 2018-2021}

Norræna ráðherranefndin er albjóðastofnun sem var komið á fót af ríkisstjórnum Norðurlandanna árið 1971 og er bví eitt elsta svæðasamstarf í heimi ${ }^{4}$. Norrænu forsætisráðherrarnir bera meginábyrgð á vinnu Norrænu ráðherranefndarinnar og 11 ráðherranefndir eiga að greiða fyrir pólitískri umræðu og sjá um framkvæmd samstarfsins á samstarfssviðunum. pað er ein pverfagleg ráŏherranefnd (norrænu samstarfsráðherrarnir/ MR-SAM) og 10 fagráðherranefndir ${ }^{5}$. MR-SAM ber daglega ábyrgð á almennu samstarfi Norrænu ráðherranefndarinnar, par á meðal ábyrgð á alpjóðastarfi. MR-SAM og Norræna samstarfsnefndin (NSK) bera pannig ábyrgð á vinnu Norrænu ráðherranefndarinnar á norðurskautssvæðinu.

Skrifstofa Norrænu ráðherranefndarinnar vinnur með prjú almenn markmið: (1) að eiga frumkvæði að, hrinda af stað, framkvæma og fylgja eftir pólitískum ákvörðunum, (2) að próa pekkingu sem grundvöll sameiginlegra lausna og (3) að byggja upp tengslanet til miðlunar reynslu og hugmynda. Pessi verkefni vinnur skrifstofan að beiðni og með umboði frá ráðherranefndunum. Vinnu skrifstofunnar er stjórnað af pólitískum markmiðum hverju sinni, stefnumörkun og öðrum stefnumótandi skjölum fyrir vinnu Norrænu ráðherranefndarinnar, til dæmis framtíðarsýn norrænu samstarfsráðherranna frá árinu 2014 um norrænt samstarf ${ }^{6}$, verkefni forsætisráðherranna Nordic Solutions to Global Challenges ${ }^{7}$, árlegum formennskuáætlunum til skiptis í löndunum ${ }^{8}$, pverfaglegri stefnu Norrænu ráðherranefndarinnar ${ }^{9}$ og samstarfsáætlunum - í pessu tilviki samstarfsáætlun Norrænu ráðherranefndarinnar um norðurskautssvæðið. 


\section{Viðmið fyrir samstarfsáætlun Norrænu ráðherranefndarinnar um norðurskautssvæðið 2018-2021}

\section{Formleg norræn viơmið}

Samstarfsverkefni eiga fyrst og fremst að stuðla að og veita aðstoð við framkvæmd og próun hnattrænnar sjálfbærniáætlunar norðurskautssvæðisins með tilliti til sýnilegs svæðisbundins og staðbundins árangurs á svæðinu. Um leið eru samstarfsverkefnin, sem styrkt eru, skuldbundin til að gefa af sér virðisauka, sem er skapaður fyrir tilstilli stuðnings Norrænu ráoherranefndarinnar. Með öðrum orðum á pessi virðisauki að gefa af sér norrænt notagildi. Pað eru margar leiðir til að ná fram norrænu notagildi og viðmiðin hér á eftir eru sumar peirra krafna, sem uppfylla parf, til pess að koma til álita við að fá stuðning frá samstarfsáætluninni um norðurskautssvæðið.

\section{Alpjóð̆leg samvinna og samstarf}

Meginreglan er sú að prjú norræn ríki eigi að taka pátt í samstarfsverkefni. Alpjóðlega samvinnu priggja norrænna ríkja má auka með einu eða fleiri priðju löndum - t.d. einu eða fleiri af hinum norðurskautsríkjunum (Bandaríkjunum, Kanada og Rússlandi). Í mati á umsóknum verður lögð áhersla á eftirfarandi viðmið:

- Að samstarfsverkefnið sýni sannanleg jákvæð áhrif með sameiginlegum norrænum/norðurskautssvæðislausnum (umfram verkefni sem unnið er í hverju landi fyrir sig).
- Að samstarfsverkefni skili sýnilegum svæðisbundnum og staðbundnum árangri á norðurskautssvæðinu.

- Að samstarfsverkefni sýni fram á og/ eða prói norræna/norðurskautssvæðissamkennd.

- Að samstarfsverkefni auki norræna færni og samkeppnishæfni.

- Að samstarfsverkefni skapi nýja og nýskapandi pekkingu og/eða nýja alpjóðlega samvinnu, sem skapar nýja og nýskapandi nálgun við próunina á norðurskautssvæðinu.

- Að samstarfsverkefni stuðli að auknum norrænum heildaráhrifum á alpjóðavettvangi.

- Að samstarfsverkefni séu kynnt út á við.

Pegar sótt er um fjármagn frá samstarfsáætluninni um norðurskautssvæðið, mun verða kafli í umsóknarformi Norrænu ráðherranefndarinnar, par sem fylla skal út nauðsynlegar upplýsingar.

\section{Pólitískt vægi}

Árið 2014 var hrint af stað umbótastarfi á vinnu Norrænu ráðherranefndarinnar (Ný Norðurlönd), sem leitast við að auka vægi pólitísks starfs í norrænu samstarfi og gera pað sýnilegra. Petta á einnig við um vinnu Norrænu ráðherranefndarinnar með norðurskautssvæðið. Viðmiðið um stuðning við samstarfsverkefni er að pau eigi að stuðla að pví að viðhalda, skapa og próa viðeigandi pólitíska dagskrá í 
almennu starfi Norrænu ráðherranefndarinnar. Núverandi pólitíska dagskrá Norrænu ráoherranefndarinnar má m.a. finna í eftirfarandi stefnumótunarskjölum:

- Yfirlýsing samstarfsrádherranna um framtíðarsýn fyrir Norrænu ráðherranefndina:

http://www.norden.org/is/ norraena-radherranefndin/ samstarfsradherrarnir-mr-sam/ yfirlysingar/nordurloend-2013saman-erum-vid-oeflugri

- Formennskuáætlun síðastliðins, núverandi og komandi árs: http://www.norden.org/is/norraenaradherranefndin/ regeringssamarbejdet/formennskai-norraenu-radherranefndinni

- Pverfagleg stefna Norrænu rádherranefndarinnar

Stefnan í málefnum barna og ungmenna: http://urn.kb.se/resolve? urn=urn:nbn:se:norden:org:diva-4633

Stefnan um jafnréttismál: http://urn.kb.se/resolve?urn=urn: nbn:se:norden:org:diva-3856
Sjálfbærnistefnan: http://urn.kb.se/re solve?urn=urn:nbn:se:norden:org:di va-530

- Norræna fjárhagsáætlunin fyrir við̌komandi ár: http://www.norden. org/is/norraena-radherranefndin/ um-norraenu-radherranefndina/ fjarhagsaaetlanir

- Núverandi samstarfsáætlun fyrir fagsviðið: http://www.norden.org/is/ norraena-radherranefndin/ radherranefndir 


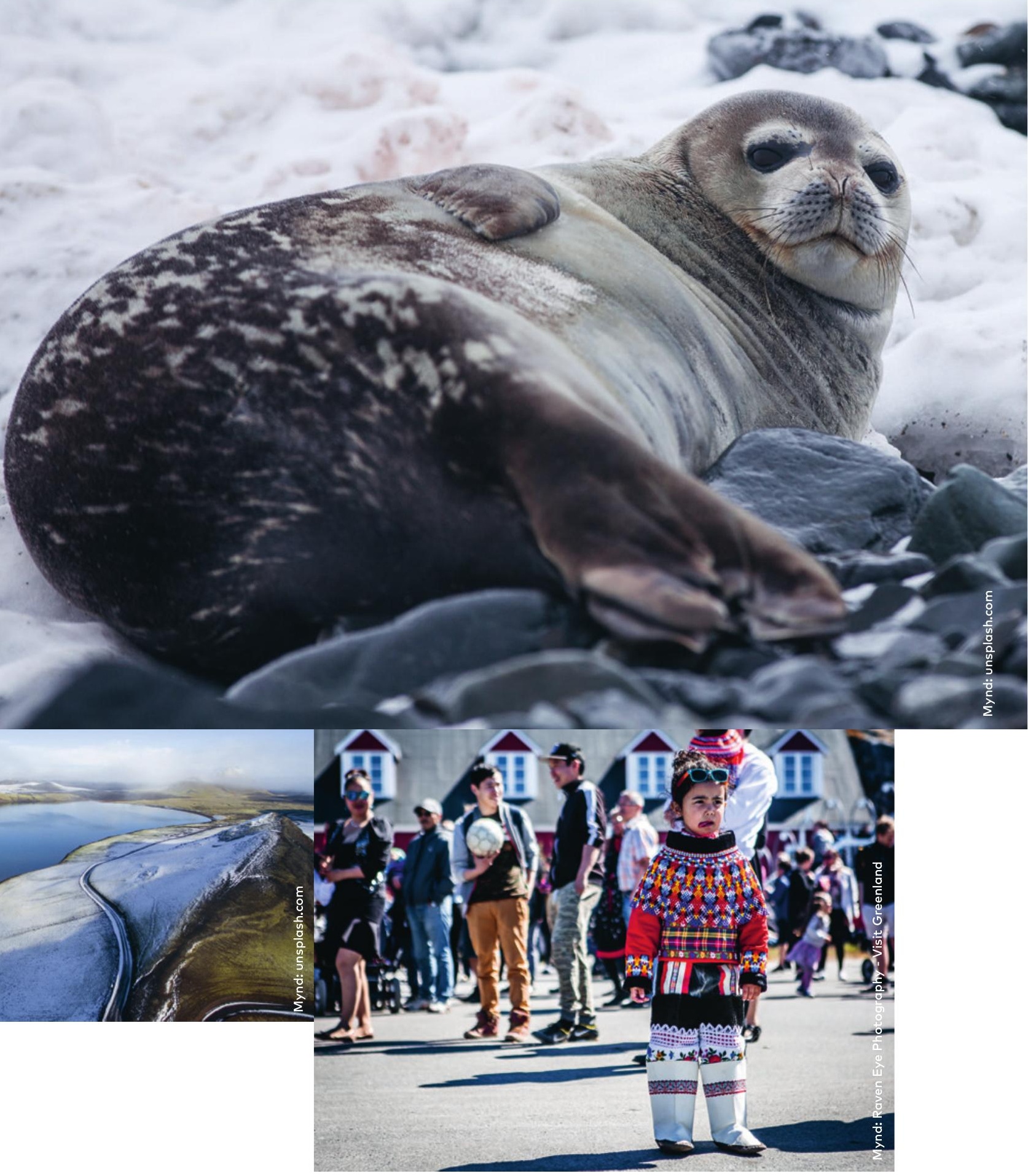




\section{Samskipti, sýnileiki og mat}

Í tengslum við umbótastarfið Ný

Norðurlönd og óskir landanna um aukið pólitískt vægi og aukinn sýnileika norræns samstarfs eiga öll samstarfsverkefni í samstarfsáætlun Norrænu ráðherranefndarinnar um norðurskautssvæðið að taka á samskiptum og flétta inn samskiptaáætlun fyrir verkefnið. Petta atriði mun einnig koma fram í umsóknarforminu. Viðmiðunarreglur Norrænu ráðherranefndarinnar um gerð samskiptaáætlunar má sjá hér til innblásturs: http://urn.kb.se/resolve?urn =urn:nbn:se:norden:org:diva-3914.
Sé pess óskað að gefa út niðurstöður verkefnis, er meginreglan að pað fari fram á vegum útgáfudeildar Norrænu ráðherranefndarinnar. Viðmiðunarreglur hér að lútandi má sjá hér: http://www.norden.org/is/ utgafurit/vidmidunarreglur-umutgafu-rita.

Til viðbótar parf að sampætta áætlun um mat, en pað mun einnig koma fram í umsóknarforminu. 


\section{Fjárhagsáætlun fyrir samstarfsáætlun Norrænu ráðherranefndarinnar um norðurskautssvæðið 2018-2021}

Fjárhagsárið fyrir fjárhagsáætlun Norrænu ráðherranefndarinnar er almanaksárið. Fjárhagsáætlunin fyrir samstarfsáætlun Norrænu ráðherranefndarinnar um norðurskautssvæðið fylgir föstum verkferlum fjárlagavinnu Norrænu ráoherranefndarinnar. Fjárhagsáætlunin hlýtur formlegt sampykki á árlegu pingi Norðurlandaráðs í viku 44 ár hvert.

Fjárhagsáætlun samstarfsáætlunar Norrænu ráðherranefndarinnar um norðurskautssvæðið skiptist í tvo almenna hluta: (1) pólitískan forgangshluta, sem veitir löndunum forgangsrétt og tækifæri til að hrinda af stað pólitískum forgangsverkefnum, aðgerðum og/eða verkefnum innan ramma áætlunarinnar; og (2) opinn umsóknarhluta, sem er opinn öllum umsækjendum, sem uppfylla markmið áætlunarinnar og uppfylla pau skilyrði sem sett eru hverju sinni. Árlegar fjárveitingar í samstarfsáætlunina um norðurskautssvæðið og skipting fjárveitingar í tvo hluta munu koma fram í sampykktri fjárhagsáætlun á fjárhagsári hverju sinni.
Stjórnun samstarfsáætlunar Norrænu ráoherranefndarinnar um norourskautssvæơið

Samstarfsráðherrarnir (MR-SAM)

bera meginábyrgð á samstarfsáætluninni um málefni norðurskautssvæðisins og par með talinni framkvæmd og umsjón með áætluninni. Hægt er að skipa norræna ráðgjafarnefnd um málefni norðurskautssvæðisins til að aðstoða við árlega framkvæmd samstarfsáætlunarinnar um norðurskautssvæðið, auk pess sem hægt er að bjóða út umsjón opnu umsóknarlotunnar fyrir samstarfsáætlunina um norðurskautssvæðið. Frekari upplýsingar um stjórnun og umsjón með samstarfsáætluninni um norðurskautssvæðið munu koma fram á vefsíðu Norrænu ráðherranefndarinnar.

Ef frekari almennar upplýsingar óskast um samstarfsáætlunina um norðurskautssvæðið er hægt að hafa samband við alpjóðateymi skrifstofu Norrænu ráðherranefndarinnar og hlutaðeigandi ráðgjafa fagsviðsins. 


\section{Athugasemdir}

1 Pverfagleg stefna fyrir börn og ungmenni; stefnan um jafnrétti og stefnan um sjálfbæra próun.

2 Dagskrá 2030: https://doi.org/10.6027/ANP2017-738

3 2030-kynslóðin: http://www.un.org/ sustainabledevelopment/ sustainable-development-goals/

4 Nánari upplýsingar á www.norden.org

5 Fagráðherranefndirnar 10 vinna með (1) vinnumál, (2) efnahagsog fjármálastefnu, (3) fiskveiðar og fiskeldi, landbúnað, matvæli og skógrækt, (4) jafnréttismál, (5) menningarmál, (6) löggjafarsamstarf, (7) umhverfismál, (8) atvinnu-, orkuog byggðastefnu, (9) félags- og heilbrigðismál og (10) menntamál og rannsóknir.

http://www.norden.org/is/ norraena-radherranefndin/ samstarfsradherrarnir-mr-sam/ yfirlysingar/nordurloend-2013saman-erum-vid-oeflugri
7 Verkefni forsætisráðherranna var sampykkt af norrænu forsætisráðherrunum á pingi Norðurlandaráðs 2015.

8 Árið 2017 gegnir Noregur formennsku í Norrænu ráðherranefndinni með eigin formennskuáætlun. Árið 2018 tekur Svípjód við formennskunni, árið 2019 tekur Ísland við formennskunni, árið 2020 tekur Danmörk við formennskunni og árið 2021 tekur Finnland við formennskunni.

9 Pverfagleg stefna Norrænu ráðherranefndarinnar skiptist í stefnu fyrir (1) börn og ungmenni, (2) jafnréttismál og (3) sjálfbærni, en undir pá stefnu heyra Dagskrá 2030 og vinnan með sjálfbærnimarkmið SP (Sustainable Development Goals (SDGs)). 
Norræna ráŏherranefndin

Nordens Hus

Ved Stranden 18

1061 København K

www.norden.org

\section{Norrænt samstarf um norðurskautssvæðið}

Norrænt samstarf um norðurskautssvæðið er samstarfsáætlun Norrænu ráðherranefndarinnar um norðurskautssvæðið á tímabilinu 2018-2021. Petta er áttunda samstarfsáætlun Norrænu ráðherranefndarinnar um norðurskautssvæðið síðan 1996.

Norðurskautssvæðið er svæði sem tekur örum breytingum. pörf er á verndun og próun á norðurskautssvæðinu. Í pví skyni að skapa pá próun sem vænst er á norðurskautssvæðinu er pörf fyrir samfellt, kerfisbundið og stöðugt samstarf. Norræna rádherranefndin vill leggja sitt af mörkum með norrænu samstarfi um norðurskautssvæðið.

Norræna ráðherranefndin hefur sett sér markmið um að koma á sjálfbærri próun á norðurskautssvæðinu. Norrænt samstarf um norðurskautssvæðið 2018-2021 mun vinna að sjálfbærri próun á norðurskautssvæðinu á grundvelli fjögurra forgangssviða:

- Peoples

- Planet

- Prosperity

- Partnerships 